\title{
Pharmacological therapy for patients with chronic thromboembolic pulmonary hypertension
}

\author{
Marius M. Hoeper
}

Affiliation: Dept of Respiratory Medicine, Hannover Medical School and German Centre for Lung Research (DZL), Hannover, Germany.

Correspondence: Marius M. Hoeper, Dept of Respiratory Medicine, Hannover Medical School and German Centre for Lung Research (DZL), 30623 Hannover, Germany. E-mail: Hoeper.Mariusamh-hannover.de

ABSTRACT Chronic thromboembolic pulmonary hypertension (CTEPH) is a rare but life-threatening disease resulting from unresolved thromboembolic obstructions. Pulmonary endarterectomy (PEA) surgery is the gold-standard treatment as it is potentially curative; however, not all patients are deemed operable and up to one-third have persistent or recurrent CTEPH after the procedure. Pulmonary arterial hypertension (PAH) and CTEPH have similar clinical presentations and histopathological features, so agents shown to be effective in PAH have often been prescribed to patients with CTEPH in the absence of proven therapies. However, clinical evidence for this strategy is not compelling. A number of small uncontrolled trials have investigated endothelin receptor antagonists, prostacyclin analogues and phosphodiesterase type 5 inhibitors in CTEPH with mixed results, and a phase III study of the endothelin receptor antagonist bosentan met only one of its two co-primary end-points. Recently, however, the soluble guanylate cyclase stimulator, riociguat, was approved in the USA and Europe for the treatment of inoperable or persistent/recurrent CTEPH following positive results from the phase III CHEST study (Chronic Thromboembolic Pulmonary Hypertension Soluble Guanylate Cyclase-Stimulator Trial). This article reviews the current evidence for the use of pharmacological therapies in CTEPH.

@ERSpublications

A review of pharmacological treatment of inoperable or persistent/recurrent CTEPH and the future standard of care http://ow.ly/KMUQV

\section{Introduction}

Chronic thromboembolic pulmonary hypertension (CTEPH) is a rare but potentially fatal disease. Unresolved thromboembolic obstructions can cause the formation of scar tissue, which, in turn, can partially or completely block the pulmonary arteries. Blood flow is redistributed and high intravascular pressures can result in vascular remodelling and hypertension [1]. CTEPH is associated with significant morbidity and mortality, and with no intervention, prognosis is poor [2, 3]. In one study involving 76 patients, those with haemodynamic signs of right heart failure survived an average of 1.7 years after catheterisation. Patients without right heart failure survived an average of 4.3 years. In patients with mean pulmonary artery pressure $>50 \mathrm{mmHg}$, 2-year survival was 20\% [2].

All patients with CTEPH should receive life-long therapy with anticoagulants, mostly vitamin $\mathrm{K}$ antagonists. This is thought to prevent in situ pulmonary artery thrombosis and recurrent venous thromboembolism [4]; however, anticoagulation therapy has not been investigated as a treatment for

Received: Feb 62015 | Accepted after revision: March 192015

Conflict of interest: Disclosures can be found alongside the online version of this article at err.ersjournals.com

Provenance: Publication of this peer-reviewed article was sponsored by Bayer Pharma AG, Berlin, Germany (principal sponsor, European Respiratory Review issue 136).

Copyright CERS 2015. ERR articles are open access and distributed under the terms of the Creative Commons Attribution Non-Commercial Licence 4.0. 
CTEPH in randomised controlled trials (RCTs). Oxygen therapy and diuretics can also be given, yet there are no data on how they affect survival [5].

Pulmonary endarterectomy (PEA) to remove thromboembolic material has become the gold-standard treatment option for patients with CTEPH as it is potentially curative, is associated with a reduced mortality rate, and leads to sustained improvements in pulmonary haemodynamics and exercise capacity (reviewed by Jenkins [6] in this issue of the European Respiratory Review). Analysis of an international CTEPH registry found that the mortality rate post-PEA was $5 \%$ up to 1 year after surgery [7].

However, not all patients with CTEPH are suitable for PEA. For some, the blockage is not accessible by surgery; others may have comorbidities that make the operation a high risk, and a proportion of patients opt not to have the procedure. Furthermore, although PEA can cure CTEPH in some patients, up to 35\% may have persistent/recurrent CTEPH following surgery. For these patients, there is a strong rationale for the consideration of targeted therapies, and current guidelines support this [8].

More recently, balloon pulmonary angioplasty (BPA) has emerged as an alternative intervention for patients ineligible for PEA. BPA was first described in 2001 [9], and several subsequent studies have shown that BPA can lead to haemodynamic improvements that are comparable to those typically seen following PEA [10-13]. However, current guidelines state that BPA requires further evaluation before it can be recommended for patients with $\mathrm{CTEPH}$, due to concerns over potential complications such as vessel rupture and reperfusion lung injury, and a lack of data showing long-term outcomes [14].

\section{Rationale for targeted medical therapy in CTEPH}

Idiopathic pulmonary arterial hypertension (PAH) is a chronic condition resulting from a sustained elevated pulmonary artery pressure in the absence of a family history or known risk factors [15]. As summarised in a review by BERGER et al. [16], there are many similarities in the vascular changes and haemodynamics observed in CTEPH and idiopathic PAH. Moreover, examination of the small pulmonary arteries in biopsies from patients with CTEPH found changes comparable to those observed in samples from patients with $\mathrm{PAH}$, indicating that the two conditions could not be distinguished by histopathological findings alone [17]. These findings suggested that PAH and CTEPH may share common pathophysiological pathways [18].

Plasma levels of the vasoconstrictor endothelin (ET)-1 correlate with haemodynamics and clinical disease severity in both PAH and CTEPH. Patients with PAH have raised levels of ET-1, which plays a role in the pathobiology of the disorder, and ET-1 receptor antagonists have shown beneficial clinical effects in patients with PAH [19]. Likewise, two clinical studies showed that ET-1 levels were higher in patients with CTEPH compared with controls [20, 21].

$\mathrm{NO}$ is a key regulator of vasodilation in the lung. NO binds to soluble guanylate cyclase (sGC) [22, 23], which catalyses the synthesis of the vasoactive mediator cyclic guanosine monophosphate (cGMP), which, via cGMP-dependent protein kinase and myosin light chain phosphatase, causes the dephosphorylation of contractile protein myosin in the vascular smooth muscle, resulting in relaxation of the vascular wall [24]. In pulmonary hypertension, endothelial dysfunction leads to impaired NO synthesis and insufficient stimulation of the NO-sGC-cGMP pathway [23]. Furthermore, reduced endogenous NO levels have been found in patients with PAH and CTEPH [23]. The sGC stimulator riociguat has shown beneficial effects in both PAH and CTEPH indications $[25,26]$.

The phosphodiesterase (PDE) superfamily of enzymes inactivates and degrades cGMP. PDE-5 is expressed abundantly in the vascular smooth muscle of the pulmonary vasculature and is also upregulated in PAH [27]. PDE-5 inhibitors have shown efficacy in patients with PAH [28, 29].

Prostacyclin is a potent pulmonary vasodilator synthesised in the pulmonary endothelium that has anti-thrombotic, anti-proliferative, anti-mitogenic and immunomodulatory properties [30,31]. Prostacyclin binding to the IP receptor triggers synthesis of cyclic adenosine monophosphate (cAMP) via adenylate cyclase. cAMP causes dephosphorylation of myosin via protein kinase A and myosin light chain phosphatase [32]. Prostacyclin synthase and prostacyclin metabolites are reduced in the pulmonary vasculature and blood serum of patients with $\mathrm{PAH}$ [33]. Prostanoids are synthetic analogues of prostacyclin recommended for the treatment of patients with PAH [34]. In some historical cases, they have also been used off-label to treat patients with CTEPH [35].

As well as pathological parallels between PAH and CTEPH, clinical presentation can also be similar. The most common presenting symptoms in patients with CTEPH include dyspnoea, oedema, fatigue and chest pain [36]. The most common presenting symptom in patients with PAH is persistent dyspnoea when exercising, while chest pain, fatigue, weakness, light-headedness and syncope may also occur [37]. 
Based on this rationale, and prior to the recent approval of riociguat for inoperable and persistent/ recurrent CTEPH, a considerable number of patients with CTEPH have been prescribed drugs approved for PAH off-label. An international CTEPH registry of 679 newly diagnosed patients found that 38\% initiated treatment with drugs approved for PAH at the time of diagnosis. This figure was highly country dependent, ranging from $2.2 \%$ to $88.9 \%$ [36]. A recent retrospective study of six European countries reported that, between 2006 and 2009, 60\% of patients with CTEPH had received an endothelin receptor antagonist, $34 \%$ a PDE-5 inhibitor and $6 \%$ a prostacyclin analogue [38].

Prescription rates for nonapproved agents in CTEPH have been increasing over time. In the USA, the proportion of patients with CTEPH who received a targeted therapy increased from $20 \%$ in 2005 to $37 \%$ in 2007 [39]. These therapies are generally offered to patients with CTEPH with poor haemodynamics prior to PEA, although data suggest that they do not have a significant impact on surgical outcomes and may even delay the potentially curative surgery [39]. A more dramatic rise was observed in the UK from $29 \%$ to $65 \%$ in patients undergoing PEA, and from $70 \%$ to $90 \%$ in patients with inoperable disease, between 2001 and 2006 [40].

\section{Clinical evidence for pharmacological therapy in CTEPH Large RCTs of pharmacological therapies in CTEPH}

To date, the only large RCTs that have assessed the efficacy and safety of pharmacological treatments in patients with CTEPH are the Chronic Thromboembolic Pulmonary Hypertension Soluble Guanylate Cyclase-Stimulator Trial (CHEST)-1 [26] and the Bosentan Effects in Inoperable Forms of Chronic Thromboembolic Pulmonary Hypertension (BENEFiT) studies [41].

\section{Riociguat: the CHEST study}

Riociguat is the first member of a novel class of therapeutics known as the sGC stimulators. It has a dual mode of action, increasing the sensitivity of sGC to endogenous NO, and also increasing sGC activity independently of $\mathrm{NO}$, resulting in vasodilation and other disease-modifying effects, such as anti-fibrotic, anti-proliferative and anti-inflammatory activity [23].

An open-label phase II study demonstrated favourable efficacy and safety results in 75 patients with inoperable CTEPH or PAH. Riociguat increased 6-min walking distance (6MWD) and reduced pulmonary vascular resistance (PVR) in patients with CTEPH or PAH compared with baseline $(\mathrm{p}<0.0001$ for all). An improvement in World Health Organization functional class (WHO-FC) was observed in 31\% of patients. Most drug-related adverse events (AEs) were mild to moderate and three patients discontinued the study. The most common AEs reported were dyspepsia, headache and hypotension [42].

Based on the results from this trial, the phase III CHEST study was initiated in 261 patients with inoperable CTEPH or persistent/recurrent pulmonary hypertension after PEA [26]. Patients were randomised to receive placebo or riociguat, individually adjusted to a maximum dose of $2.5 \mathrm{mg}$ three times daily. The primary end-point was mean change in $6 \mathrm{MWD}$ at week 16 . The results showed that the $6 \mathrm{MWD}$ increased by $39 \mathrm{~m}$ in the riociguat group, versus a decrease of $6 \mathrm{~m}$ in the placebo group after 16 weeks of treatment $(\mathrm{p}<0.001)$. The secondary end-point of changes in PVR was also met (table 1). A decrease in PVR of $226 \mathrm{dyn} \cdot \mathrm{s} \cdot \mathrm{cm}^{-5}$ was observed in the riociguat group, versus an increase of $23 \mathrm{dyn} \cdot \mathrm{s} \cdot \mathrm{cm}^{-5}$ in the placebo group $(\mathrm{p}<0.001)$. Riociguat was also associated with significant improvements in $\mathrm{N}$-terminal pro-brain natriuretic peptide $(\mathrm{NT}-$ proBNP) levels $(\mathrm{p}<0.001)$ and WHO-FC $(\mathrm{p}=0.003)$. There was no significant difference in the incidence of clinical worsening events between the riociguat group and the placebo group ( $2 \%$ and $6 \%$, respectively).

The improvements in primary and secondary end-points were similar in inoperable versus persistent/ recurrent disease, although the effect on 6MWD was not significant in the persistent/recurrent group [43]. In general, there was a greater numerical effect in the inoperable patients.

AEs were mainly mild to moderate in nature and the most common were headache and dizziness. The most frequently occurring serious AEs were right ventricular failure (3\% in both groups) and syncope (2\% of the riociguat group and $3 \%$ of the placebo group).

An open-label extension study (CHEST-2) was offered to the 243 patients who completed the CHEST-1 study, and 237 (98\%) enrolled. At 1 year, the improvement in 6MWD seen in the CHEST-1 study had been maintained (fig. 1), and survival was $97 \%$ (fig. 2) [44].

As of March 2014, 72\% had received riociguat for $\geqslant 2$ years. The latest analysis showed that improvements in 6MWD and WHO-FC have been maintained for up to 2 years (mean \pm SD $6 \mathrm{MWD}$ had increased from CHEST-1 baseline by $50 \pm 68 \mathrm{~m}(\mathrm{n}=162)$; WHO-FC had improved/stabilised/worsened compared with baseline by $39 \% / 58 \% / 3 \%(n=170))$, with an estimated survival rate of $93 \%$. The long-term safety profile 
TABLE 1 Change from baseline in primary and selected secondary end-points with riociguat and placebo in the Chronic Thromboembolic Pulmonary Hypertension Soluble Guanylate Cyclase-Stimulator Trial (CHEST)-1 study

\begin{tabular}{|c|c|c|c|c|c|c|c|}
\hline \multirow[t]{2}{*}{ End-point } & \multicolumn{3}{|c|}{ Placebo } & \multicolumn{3}{|c|}{ Riociguat } & \multirow[t]{2}{*}{ p-value $\#$} \\
\hline & Patients & Baseline & Change & Patients & Baseline & Change & \\
\hline \multicolumn{8}{|l|}{ Primary end-point } \\
\hline \multicolumn{8}{|l|}{$\begin{array}{l}\text { Selected secondary } \\
\text { end-points }\end{array}$} \\
\hline PVR dyn $\cdot \mathrm{s} \cdot \mathrm{cm}^{-5}$ & 82 & $779 \pm 401$ & $23 \pm 274$ & 151 & $791 \pm 432$ & $-226 \pm 248$ & $<0.001$ \\
\hline & & $\begin{array}{l}\text { Class II: } 25(24 \%) \\
\text { Class III: } 60(69 \%)\end{array}$ & $\begin{array}{l}\text { moved to } \\
\text { lower class. }\end{array}$ & & $\begin{array}{l}\text { Class II: } 55(32 \%) \\
\text { Class III: } 107 \text { (62\%) }\end{array}$ & $\begin{array}{l}\text { to lower class; } \\
107(62 \%) \text { stayed }\end{array}$ & \\
\hline & & Class IV: $2(2 \%)$ & $68(78 \%)$ & & Class IV: 8 (5\%) & the same; $9(5 \%)$ & \\
\hline & & & stayed the & & & moved to higher & \\
\hline & & & same; 6 (7\%) & & & class & \\
\hline & & & $\begin{array}{l}\text { moved to } \\
\text { higher class }\end{array}$ & & & & \\
\hline
\end{tabular}

Data are presented as $\mathrm{n}$ or mean $\pm \mathrm{SD}$, unless otherwise stated. 6MWD: 6-min walking distance; PVR: pulmonary vascular resistance; NT-proBNP: N-terminal pro-brain natriuretic peptide; WHO-FC: World Health Organization functional class. "\#: calculated with the use of stratified Wilcoxon test for the change from baseline to last visit. Reproduced and modified from [26] with permission from the publisher.

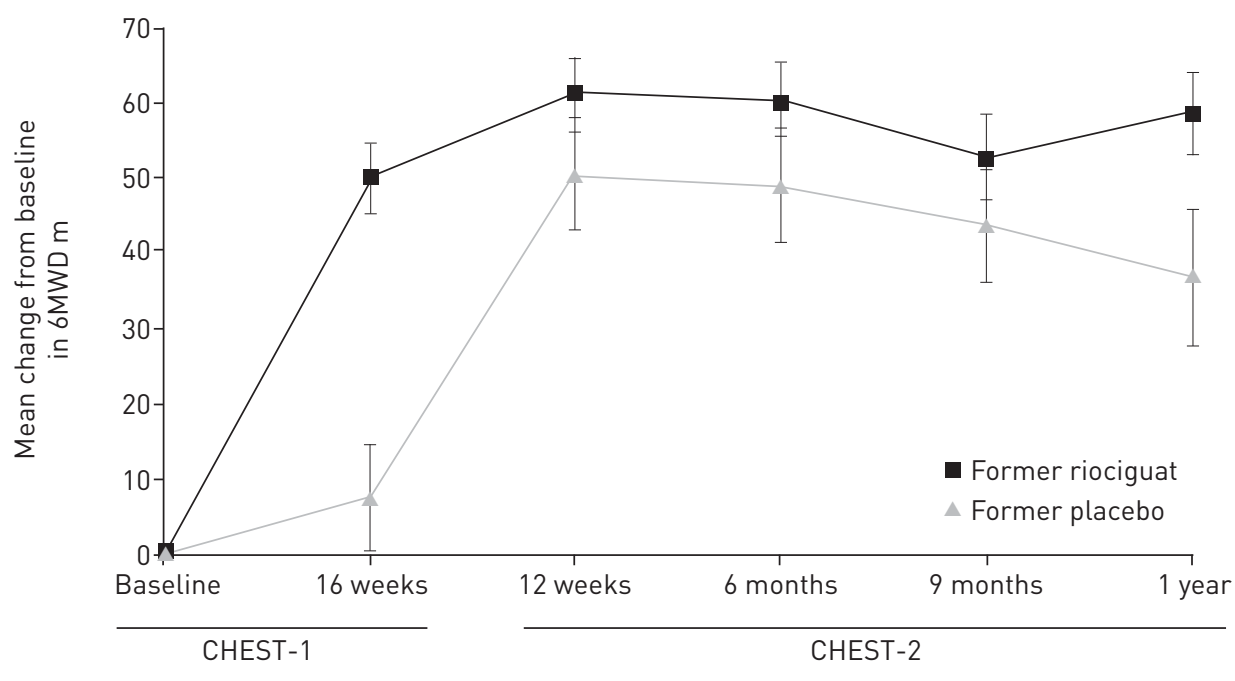

Mean 6MWD absolute values $m$

$\begin{array}{lcccccc}\text { Former riociguat } & 345 & 396 & 406 & 406 & 400 & 411 \\ \text { Placebo } & 360 & 368 & 414 & 411 & 408 & 405 \\ \text { Patients n } & & & & & & \\ \text { Former riociguat } & 155 & 154 & 145 & 143 & 143 & 114 \\ \text { Placebo } & 82 & 81 & 75 & 75 & 72 & 58\end{array}$

FIGURE 1 Mean change from baseline in 6-min walking distance (6MWD) in the Chronic Thromboembolic Pulmonary Hypertension Soluble Guanylate Cyclase-Stimulator Trial (CHEST)-1 and CHEST-2 studies. Data are observed values; error bars represent SEM. Reproduced from [44] with permission from the publisher.

was good, with only $5 \%$ of patients withdrawing due to AEs. Syncope was observed in seven (3\%) patients. In the CHEST-1 study, seven patients in the riociguat group had haemoptysis or pulmonary haemorrhage, compared with zero in the placebo group. In the CHEST-2 study, there were eight additional events of haemoptysis or pulmonary haemorrhage [45]. A causal relationship between haemoptysis/pulmonary 

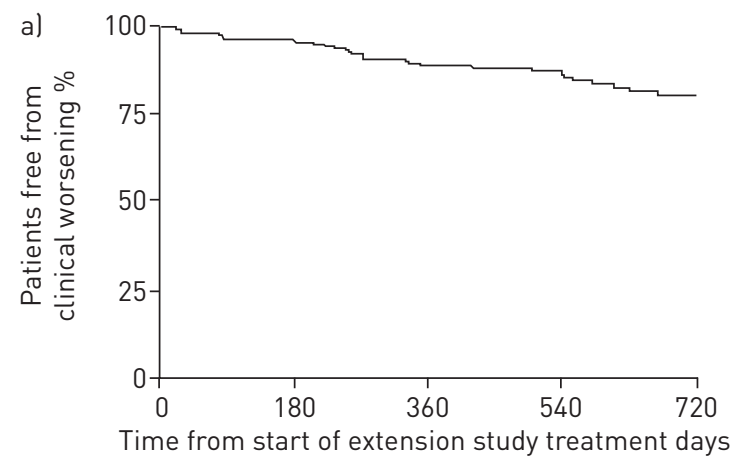

Patients who reached 237 time point without clinical worsening $n$

Patients with clinical worsening $n$

$\begin{array}{llll}218 & 155 & 96 & 65 \\ 10 & 24 & 28 & 34\end{array}$
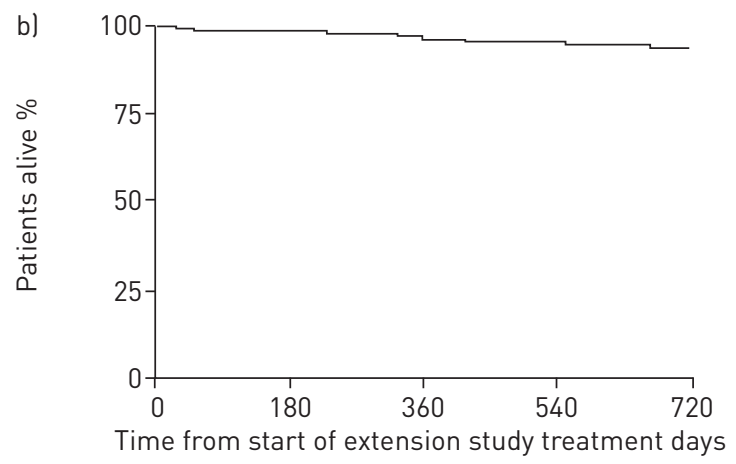

Patients alive 237 at time point $n$

Deaths $\mathrm{n}$
223

166

105

74

0

3

8

10

FIGURE 2 Kaplan-Meier plots for a) clinical worsening and b) survival in the overall population during the Chronic Thromboembolic Pulmonary Hypertension Soluble Guanylate Cyclase-Stimulator Trial (CHEST)-2 study. At 1 year, the estimated rate of clinical worsening-free survival was $88 \%$ and the estimated rate of survival was $97 \%$. Reproduced from [44] with permission from the publisher.

haemorrhage and riociguat has not been established, but the potentially increased risk of these events with riociguat is reflected by a warning on the label.

The findings from the CHEST study led to the approval of riociguat for the treatment of patients with inoperable CTEPH and persistent/recurrent CTEPH after PEA in the USA [46], Europe and several other countries [47]. Riociguat is currently the only therapeutic agent approved for the pharmacological treatment of CTEPH.

\section{Bosentan: the BENEFIT study}

The BENEFiT study compared bosentan, an orally active dual endothelin receptor antagonist, with placebo in 157 patients with inoperable or persistent/recurrent CTEPH over 16 weeks [41]. The study had independent co-primary end-points: change from baseline in PVR and change from baseline in 6MWD after 16 weeks of therapy. Secondary end-points included WHO-FC and time to clinical worsening. NT-proBNP was evaluated as an exploratory end-point.

Results demonstrated a significant decrease in PVR $(\mathrm{p}<0.0001)$ and an increase in cardiac index $(\mathrm{p}=0.0007)$ for bosentan-treated patients versus placebo. There was also a significant decrease in NT-proBNP levels $(\mathrm{p}=0.0034)$. However, bosentan therapy did not significantly improve 6MWD, WHO-FC or time to clinical worsening (table 2). Bosentan had similar effects on 6MWD and PVR in patients with inoperable versus persistent/recurrent CTEPH.

Generally, bosentan was well tolerated. The three most common side-effects were peripheral oedema, abnormal liver function and headache. Hepatic events are known to occur with bosentan and, in this study, elevated levels of liver function enzymes ( $>3 \times$ upper limit of normal) were observed in $14.5 \%$ of bosentan-treated patients versus $3.8 \%$ of placebo.

Based on the absence of demonstrable clinical benefits, bosentan is not currently approved for use in patients with CTEPH.

\section{Ongoing RCT with macitentan in CTEPH}

MERIT-1 (NCT02021292) is a phase II, placebo-controlled study investigating macitentan in 78 patients with inoperable CTEPH over 24 weeks. The primary end-point is change in PVR. An open-label extension study is planned (MERIT-2; NCT02060721).

\section{Smaller studies of pharmacological therapies in CTEPH}

Smaller trials of various pharmacological therapies for CTEPH are summarised in table 3. Their divergent results are likely to be due to the different drugs and populations, their uncontrolled nature and small sample sizes. 
TABLE 2 Change from baseline in primary and selected secondary end-points with bosentan and placebo in the Bosentan Effects in Inoperable Forms of Chronic Thromboembolic Pulmonary Hypertension (BENEFiT) study

\begin{tabular}{|c|c|c|c|c|c|c|c|}
\hline \multirow[t]{2}{*}{ End-point } & \multicolumn{3}{|c|}{ Placebo } & \multicolumn{3}{|c|}{ Bosentan } & \multirow[t]{2}{*}{ p-value ${ }^{\#}$} \\
\hline & Patients & Baseline & Change & Patients & Baseline & Change & \\
\hline \multicolumn{8}{|l|}{ Co-primary end-points } \\
\hline PVR dyn $\cdot \mathrm{s} \cdot \mathrm{cm}^{-5}$ & 71 & $787(708-866)$ & $30(-25-85)$ & 66 & 778 (698-857) & $-146(-207--85)$ & $<0.0001$ \\
\hline \multicolumn{8}{|l|}{$\begin{array}{l}\text { Selected secondary } \\
\text { end-points }\end{array}$} \\
\hline
\end{tabular}

Data are presented as $\mathrm{n}$ or mean (95\% confidence interval), unless otherwise stated. 6MWD: 6-min walking distance; PVR: pulmonary vascular resistance; NT-proBNP: N-terminal pro-brain natriuretic peptide; WHO-FC: World Health Organization functional class; NS: nonsignificant \#: calculated with the use of stratified Wilcoxon test for the change from baseline and the Wilcoxon rank sum test for treatment effect; ": data for treatment effect, not change from baseline. Data from [41].

\section{Endothelin receptor antagonists}

An open-label multicentre trial involving 19 patients with inoperable CTEPH reported significant decreases in PVR, increases in 6MWD but no change in WHO-FC at 3 months [48]. Two other studies (16 and 47 patients, respectively) found improvements in New York Heart Association functional class (NYHA-FC)/WHO-FC and an increase in mean 6MWD with bosentan [49, 50].

SEYFARTH et al. [51] reported that improvements in 6MWD recorded at 6 months were maintained over 24 months. In a second study, 77 patients treated with bosentan for $>2$ years in Japan experienced significant decreases in PVR [53]. In a third study, in the Netherlands, $>2$ years of bosentan treatment led to stable NYHA-FC levels, but 6MWD had decreased slightly from the improved short-term value (although not to baseline levels) [52]. Finally, a report from a single centre in Japan demonstrated better long-term survival in patients with CTEPH receiving bosentan, or other "modern treatment" (bosentan, sildenafil and new oral drugs being trialled), than those taking conventional therapy for CTEPH (5-year survival $89 \%$ versus $60 \%, \mathrm{p}=0.047$ ) [63].

\section{Prostacyclin analogues}

Several studies have investigated prostacyclin analogues in patients with CTEPH, but most of the analyses have been performed retrospectively and the patient numbers were small [54-59].

Two studies with epoprostenol found an increase in exercise capacity [54,55]; one also demonstrated an improvement in NYHA-FC [54], while the other showed enhanced haemodynamic measurements [55]. Moreover, an open-label study of beraprost and conventional therapy versus conventional therapy found a significant decrease in PVR, and half the patients saw an improvement in NYHA-FC. Fewer deaths were recorded in the beraprost-treated group, resulting in improved survival rates at 1, 3 and 5 years [57]. Additionally, a long-term study of treprostinil in patients with PAH and CTEPH showed improvements in NYHA-FC, exercise capacity and survival when compared with historical data for untreated patients [58].

While some of these results with prostacyclin analogues are promising, large RCTs with epoprostenol, beraprost and treprostinil are lacking. However, a European multicentre RCT of inhaled iloprost versus placebo in a mixed population of patients with PAH or CTEPH has been published. A total of 203 patients were enrolled, 57 of whom were diagnosed with CTEPH. The primary end-points were improvements in 6MWD and NYHA-FC at 12 weeks, and significant increases were observed in the overall population $(\mathrm{p}=0.004$ and $\mathrm{p}=0.03$, respectively) [56]. In the group with $\mathrm{CTEPH}$, there was no significant difference for treatment response to the combined study end-point of a $10 \%$ increase from baseline in 6MWD and an improvement of one functional class (iloprost group 12.5\%, placebo 8.3\%) [64].

\section{PDE-5 inhibitors}

Sildenafil, a PDE-5 inhibitor, is licensed for the treatment of PAH and is often prescribed off-label for patients with CTEPH. In a small randomised, placebo-controlled trial with sildenafil in 19 patients with $\mathrm{CTEPH}$, significant decreases in PVR and improvements in WHO-FC were recorded, but no difference 
TABLE 3 Findings from smaller clinical studies of pharmacological therapies in patients with chronic thromboembolic pulmonary hypertension (CTEPH)

\begin{tabular}{|c|c|c|c|c|c|c|c|}
\hline Agent & First author [ref.] & Year & Study type & Duration & Patients & Mean $\pm S D$ age years & Outcomes versus baseline \\
\hline \multirow[t]{6}{*}{ Bosentan (oral) } & HoEper [48] & 2005 & Open-label & 3 months & Inoperable CTEPH (n=19) & $60 \pm 8$ & $\begin{array}{l}\text { Increase in 6MWD ( } p=0.009) \text {; decrease in PVR } \\
\quad(p<0.001) \text {; no change in WHO-FC }\end{array}$ \\
\hline & BondERMAN [49] & 2005 & Open-label & 6 months & Inoperable CTEPH (n=16) & $70 \pm 3$ & $\begin{array}{l}\text { Increase in } 6 \text { MWD }(p=0.01) \text {; decrease in NT-proBNP } \\
(p=0.01) ; \text { NYHA-FC improved for } 69 \% \text { of patients }\end{array}$ \\
\hline & HUghes [50] & 2006 & Retrospective & 12 months & $\begin{array}{l}\text { Inoperable and persistent } \\
\text { CTEPH }(n=47)\end{array}$ & $60(27-82)^{\#}$ & $\begin{array}{l}\text { Increase in } 6 \mathrm{MWD}(\mathrm{p}<0.001) \text {; no change in PVR } \\
(\mathrm{p}=0.171) ; \mathrm{WHO}-\mathrm{FC} \text { improved for } 24 \% \text { of patients }\end{array}$ \\
\hline & SEYFARTH [51] & 2007 & Open-label & 24 months & $\begin{array}{l}\text { Inoperable and persistent } \\
\text { CTEPH }(n=12)\end{array}$ & $57 \pm 15$ & $\begin{array}{l}\text { Increase in } 6 \mathrm{MWD}(p<0.005) \text { at } 6 \text { months, maintained } \\
\text { over } 24 \text { months; decrease in Tei index }(p<0.005) \text { at } \\
6 \text { months, maintained over } 24 \text { months; WHO-FC } \\
\text { improved for } 50 \% \text { of patients over } 18 \text { months }\end{array}$ \\
\hline & Post [52] & 2009 & Retrospective & $>24$ months & Inoperable CTEPH (n=18) & $63 \pm 14$ & $\begin{array}{l}\text { Increase in } 6 \mathrm{MWD}(\mathrm{p}=0.01) \text { at } 12-24 \text { months but this } \\
\text { decreased with longer treatment; nonsignificant } \\
\text { decrease in NT-proBNP ( } p=0.31) \text { at } 12-24 \text { months } \\
\text { that increased with longer treatment; NYHA-FC } \\
\text { improved ( } p=0.03 \text { ) with long-term treatment } \\
\text { (>24 months) }\end{array}$ \\
\hline & NISHIKAWA-TAKAHASHI [53] & 2014 & Retrospective & $>24$ months & Inoperable CTEPH (n=7) & $63 \pm 7$ & $\begin{array}{c}\text { No change in } 6 \text { MWD }(p=0.11) \text {; decrease in PVR } \\
(p<0.05) \text { and NT-proBNP }(p<0.05) ; \text { WHO-FC improved } \\
\text { in all patients }(p=0.005)\end{array}$ \\
\hline \multirow[t]{2}{*}{ Epoprostenol (i.v.) } & ScELSI [54] & 2004 & Retrospective & 12 months & Inoperable CTEPH (n=11) & $50 \pm 11$ (CTEPH only) & $\begin{array}{l}\text { Increase in exercise tolerance }(p=0.0006) \text {; increase in } \\
\text { clinical status; NYHA-FC improvement }(p=0.0001)\end{array}$ \\
\hline & CABRoL [55] & 2007 & Retrospective & $\begin{array}{c}\text { Mean } \\
20 \text { months }\end{array}$ & Inoperable CTEPH (n=27) & $51 \pm 13$ & $\begin{array}{c}\text { Decrease in mPAP ( } p=0.001) \text { and TPR ( } p<0.0001) \text { at } \\
3 \text { months, maintained over } 20 \text { months; NYHA-FC } \\
\text { improved for } 48 \% \text { of patients ( } p<0.0001) \text { at } 3 \text { months } \\
\text { and for } 50 \% \text { at } 20 \text { months; sustained improvement in } \\
6 \text { MWD ( } p=0.03 \text { ) at } 20 \text { months }\end{array}$ \\
\hline Iloprost (inhaled) & OLSCHEWSKI [56] & 2002 & $\begin{array}{l}\text { RCT versus } \\
\text { placebo }\end{array}$ & 12 weeks & $\begin{array}{l}\text { PAH and CTEPH (101 } \\
\text { iloprost, } 102 \text { placebo) }\end{array}$ & $\begin{array}{l}51 \pm 13 \text { (iloprost) } \\
53 \pm 12 \text { (placebo) }\end{array}$ & $\begin{array}{l}\text { Increase in 6MWD ( } p=0.004) \text {; no difference in } \\
\text { haemodynamics between iloprost and placebo; } \\
\text { NYHA-FC improvement ( } p=0.03)\end{array}$ \\
\hline Beraprost (oral) & ONo [57] & 2003 & $\begin{array}{l}\text { Retrospective, } \\
\text { beraprost+CT } \\
\text { versus CT } \\
\text { alone }\end{array}$ & $\begin{array}{l}\text { Mean } \\
36 \text { months }\end{array}$ & $\begin{array}{l}\text { Inoperable CTEPH (20 } \\
\text { beraprost+CT, } 23 \mathrm{CT} \text { ) }\end{array}$ & $\begin{array}{l}56 \pm 10 \text { (beraprost) } \\
52 \pm 14 \text { (CT) }\end{array}$ & $\begin{array}{c}\text { Decrease in TPR ( } p<0.05 \text { ) at } 2 \text { months with beraprost; } \\
\text { NYHA-FC improved for } 50 \% \text { of patients at } 2 \text { months } \\
\text { with beraprost; improved } 1-, 3-\text { and } 5 \text {-year survival } \\
\text { rates with beraprost }(100 \%, 85 \% \text { and } 76 \% \text {, } \\
\text { respectively) versus CT alone }(87 \%, 60 \% \text { and } 46 \% \text {, } \\
\text { respectively) }\end{array}$ \\
\hline \multirow[t]{2}{*}{$\begin{array}{l}\text { Treprostinil } \\
\text { (subcutaneous) }\end{array}$} & LANG [58] & 2006 & Retrospective & 36 months & $\begin{array}{l}\text { PAH (n=99) and CTEPH } \\
\qquad(n=23)\end{array}$ & $49(12-81)^{\#}$ & $\begin{array}{l}\text { Increase in } 6 \mathrm{MWD} \text { ( } \mathrm{p}=0.0001) \text {; NYHA-FC improvement } \\
(\mathrm{p}=0.0001) \text {; results consistent across all types of } \mathrm{PH}\end{array}$ \\
\hline & SkORo-SAJer [59] & 2007 & $\begin{array}{l}\text { Open-label } \\
\text { versus } \\
\text { historical } \\
\text { control }\end{array}$ & $\begin{array}{c}\text { Mean } \\
24 \text { months }\end{array}$ & Inoperable CTEPH ( $=25$ ) & $\begin{array}{l}59 \pm 13 \text { (treprostinil) } \\
62 \pm 15 \text { (control) }\end{array}$ & $\begin{array}{l}\text { Increase in 6MWD ( } p=0.01) \text {; decrease in PVR ( } p=0.01) \\
\text { and NT-proBNP }(p=0.02) \text {; WHO-FC improvement } \\
\qquad(p=0.001)\end{array}$ \\
\hline
\end{tabular}




\begin{tabular}{|c|c|c|c|c|c|c|c|}
\hline Agent & First author [ref.] & Year & Study type & Duration & Patients & Mean \pm sD age years & Outcomes versus baseline \\
\hline \multirow[t]{4}{*}{ Sildenafil (oral) } & GHoFRANI [60] & 2003 & Open-label & 6 months & Inoperable CTEPH (n=12) & NA & $\begin{array}{l}\text { Increase in 6MWD }(p=0.02) \text {; decrease in PVR } \\
\qquad(p=0.004)\end{array}$ \\
\hline & REICHENBERGER [61] & 2007 & Open-label & 12 months & Inoperable CTEPH (n=104) & $62 \pm 11$ & $\begin{array}{l}\text { Increase in } 6 M W D \text { at } 3 \text { months }(p=0.0001) \text { and } \\
12 \text { months }(p=0.0005) ; \text { decrease in PVR at } 3 \text { months } \\
(p=0.0002) ; \text { WHO-FC improvement at } 3 \text { months } \\
(p=0.01) \text { and } 12 \text { months }(p=0.001)\end{array}$ \\
\hline & SUNTHARALINGAM [62] & 2008 & $\begin{array}{l}\text { RCT versus } \\
\text { placebo }\end{array}$ & 12 weeks & $\begin{array}{l}\text { Inoperable CTEPH } \\
(9 \text { sildenafil, } 10 \text { placebo) }\end{array}$ & $\begin{array}{l}50 \pm 13 \text { (sildenafil) } \\
60 \pm 14 \text { (placebo) }\end{array}$ & $\begin{array}{l}\text { No difference in 6MWD between two groups; } \\
\text { decrease in PVR }(p=0.044) \text {; WHO-FC improvement } \\
\qquad(p=0.025)\end{array}$ \\
\hline & & & $\begin{array}{l}\text { Open-label } \\
\text { extension }\end{array}$ & 12 months & Inoperable CTEPH (n=17) & NA & $\begin{array}{l}\text { Increase in 6MWD }(p=0.014) \text {; decrease in PVR } \\
\quad(p=0.001) \text { and NT-proBNP }(p=0.004)\end{array}$ \\
\hline Riociguat (oral) & Ghofrani [26] & 2013 & $\begin{array}{l}\text { RCT versus } \\
\text { placebo }\end{array}$ & 16 weeks & $\begin{array}{l}\text { Inoperable and persistent } \\
\text { CTEPH (173 riociguat, } \\
88 \text { placebo) }\end{array}$ & $\begin{array}{l}59 \pm 14 \text { (riociguat) } \\
59 \pm 13 \text { (placebo) }\end{array}$ & $\begin{array}{c}\text { Increase in } 6 \text { MWD }(p<0.001) \text {; decrease in PVR } \\
(p<0.001) \text { and NT-proBNP }(p<0.001) \text {; WHO-FC } \\
\text { improvement }(p=0.003)\end{array}$ \\
\hline $\begin{array}{l}\text { “Modern } \\
\text { treatment": } \\
\text { bosentan, } \\
\text { sildenafil, } \\
\text { clinical trial } \\
\text { drugs }\end{array}$ & NISHIMURA [63] & 2013 & $\begin{array}{c}\text { Retrospective, } \\
\text { single-centre } \\
\text { cohort; group } 1 \\
\text { diagnosed } \\
\text { 1986-1998, } \\
\text { group 2 } \\
\text { diagnosed } \\
\text { 1999-2004, } \\
\text { group 3 } \\
\text { diagnosed } \\
2005-2010\end{array}$ & & Inoperable CTEPH (n=95) & $55 \pm 14$ & $\begin{array}{l}\text { Significantly improved survival in group } 3 \text { compared } \\
\text { with groups } 1 \text { and } 2\end{array}$ \\
\hline
\end{tabular}

6MWD: 6-min walking distance; PVR: pulmonary vascular resistance; WHO-FC: World Health Organization functional class; NT-proBNP: N-terminal pro-brain natriuretic peptide; NYHA-FC: New York Heart Association functional class; mPAP: mean pulmonary artery pressure; TPR: total pulmonary resistance; RCT: randomised controlled trial; PAH: pulmonary arterial hypertension; CT: conventional therapy; PH: pulmonary hypertension; NA: not available. " ${ }^{\text {: }}$ data presented as mean (range). 
was seen in the primary end-point, 6MWD at 12 weeks [62]. An open-label extension to this study found no significant increase in 6MWD after 12 months of treatment [62]. In two further open-label studies, sildenafil has been reported to improve exercise capacity and haemodynamics [60,61], with one reporting persistence of benefit at 12 months [61]. To date, large long-term controlled trials with sildenafil or other PDE-5 inhibitors in CTEPH are lacking.

\section{Conclusions}

PEA is the first choice of treatment for patients with CTEPH and is potentially curative; therefore, all patients should be examined and assessed for operability at an expert centre. For those patients not suitable for PEA, pharmacological therapy should be considered. Although BPA has shown promise as an alternative to PEA in a limited number of patients, further evaluation is required before this procedure can be recommended in patients with CTEPH. To date, riociguat is the only pharmacological agent approved in $\mathrm{CTEPH}$, and the only one that has demonstrated robust clinical efficacy in terms of both exercise capacity and haemodynamics in a large, well-designed RCT. Furthermore, these benefits have been sustained for up to 2 years in the long-term extension study. However, more controlled long-term data are required.

Given the availability and approval of riociguat, several new questions have now arisen in the management of CTEPH. First, will regulators accept placebo-controlled trials in the future, or will RCTs of investigational medical therapies versus riociguat (noninferiority trials) be expected? To date, there are no registered trials using riociguat as a comparator. Second, will combination studies be performed in patients with CTEPH? Combination therapies have been used successfully in PAH, as reviewed by MONTANI et al. [37]. However, the limited data available and lack of long-term studies mean there is no consensus on the use of combination strategies for CTEPH. Moreover, care is needed to avoid events such as hypotension, and for this reason PDE-5 inhibitors are contraindicated with the use of riociguat [46, 47]. Further research and long-term data are needed.

\section{Acknowledgements}

Editorial assistance was provided by Adelphi Communications Ltd (Bollington, UK), supported by Bayer Pharma AG.

\section{References}

1 Hoeper MM, Madani MM, Nakanishi N, et al. Chronic thromboembolic pulmonary hypertension. Lancet Respir Med 2014; 2: 573-582.

2 Riedel M, Stanek V, Widimsky J, et al. Longterm follow-up of patients with pulmonary thromboembolism. Late prognosis and evolution of hemodynamic and respiratory data. Chest 1982; 81: 151-158.

3 Lewczuk J, Piszko P, Jagas J, et al. Prognostic factors in medically treated patients with chronic pulmonary embolism. Chest 2001; 119: 818-823.

4 Piazza G, Goldhaber SZ. Chronic thromboembolic pulmonary hypertension. N Engl J Med 2011; 364: 351-360.

5 Cannon JE, Pepke-Zaba J. Is distal chronic thromboembolic pulmonary hypertension treatable with PAH targeted drugs? Semin Respir Crit Care Med 2013; 34: 620-626.

6 Jenkins D. Pulmonary endarterectomy: the potentially curative treatment for patients with chronic thromboembolic pulmonary hypertension. Eur Respir Rev 2015; 24: 263-271.

7 Mayer E, Jenkins D, Lindner J, et al. Surgical management and outcome of patients with chronic thromboembolic pulmonary hypertension: results from an international prospective registry. J Thorac Cardiovasc Surg 2011; 141: 702-710.

8 Wilkens H, Lang I, Behr J, et al. Chronic thromboembolic pulmonary hypertension (CTEPH): updated Recommendations of the Cologne Consensus Conference 2011. Int J Cardiol 2011; 154: Suppl. 1, S54-S60.

9 Feinstein JA, Goldhaber SZ, Lock JE, et al. Balloon pulmonary angioplasty for treatment of chronic thromboembolic pulmonary hypertension. Circulation 2001; 103: 10-13.

10 Andreassen AK, Ragnarsson A, Gude E, et al. Balloon pulmonary angioplasty in patients with inoperable chronic thromboembolic pulmonary hypertension. Heart 2013; 99: 1415-1420.

11 Kataoka M, Inami T, Hayashida K, et al. Percutaneous transluminal pulmonary angioplasty for the treatment of chronic thromboembolic pulmonary hypertension. Circ Cardiovasc Interv 2012; 5: 756-762.

12 Mizoguchi H, Ogawa A, Munemasa M, et al. Refined balloon pulmonary angioplasty for inoperable patients with chronic thromboembolic pulmonary hypertension. Circ Cardiovasc Interv 2012; 5: 748-755.

13 Sugimura K, Fukumoto Y, Satoh K, et al. Percutaneous transluminal pulmonary angioplasty markedly improves pulmonary hemodynamics and long-term prognosis in patients with chronic thromboembolic pulmonary hypertension. Circ J 2012; 76: 485-488.

14 Kim NH, Delcroix M, Jenkins DP, et al. Chronic thromboembolic pulmonary hypertension. J Am Coll Cardiol 2013; 62: Suppl. 25, D92-D99.

15 Simonneau G, Robbins IM, Beghetti M, et al. Updated clinical classification of pulmonary hypertension. J Am Coll Cardiol 2009; 54: Suppl. 1, S43-S54.

16 Berger G, Azzam ZS, Hardak E, et al. Idiopathic pulmonary arterial hypertension or chronic thromboembolic pulmonary hypertension: can we be certain? Isr Med Assoc J 2011; 13: 106-110.

17 Moser KM, Bloor CM. Pulmonary vascular lesions occurring in patients with chronic major vessel thromboembolic pulmonary hypertension. Chest 1993; 103: 685-692.

18 Ulrich S, Fischler M, Speich R, et al. Chronic thromboembolic and pulmonary arterial hypertension share acute vasoreactivity properties. Chest 2006; 130: 841-846. 
19 Galiè N, Manes A, Branzi A. The endothelin system in pulmonary arterial hypertension. Cardiovasc Res 2004; 61: 227-237.

20 Bauer M, Wilkens H, Langer F, et al. Selective upregulation of endothelin B receptor gene expression in severe pulmonary hypertension. Circulation 2002; 105: 1034-1036.

21 Reesink HJ, Meijer RC, Lutter R, et al. Hemodynamic and clinical correlates of endothelin-1 in chronic thromboembolic pulmonary hypertension. Circ J 2006; 70: 1058-1063.

22 Schmidt HH, Walter U. NO at work. Cell 1994; 78: 919-925.

23 Stasch JP, Evgenov OV. Soluble guanylate cyclase stimulators in pulmonary hypertension. Handb Exp Pharmacol 2013; 218: 279-313.

24 Francis SH, Busch JL, Corbin JD, et al. cGMP-dependent protein kinases and cGMP phosphodiesterases in nitric oxide and cGMP action. Pharmacol Rev 2010; 62: 525-563.

25 Ghofrani HA, Galiè N, Grimminger F, et al. Riociguat for the treatment of pulmonary arterial hypertension. N Engl J Med 2013; 369: 330-340.

26 Ghofrani HA, D'Armini AM, Grimminger F, et al. Riociguat for the treatment of chronic thromboembolic pulmonary hypertension. N Engl J Med 2013; 369: 319-329.

27 Corbin JD, Beasley A, Blount MA, et al. High lung PDE5: a strong basis for treating pulmonary hypertension with PDE5 inhibitors. Biochem Biophys Res Commun 2005; 334: 930-938.

28 Galiè N, Ghofrani HA, Torbicki A, et al. Sildenafil citrate therapy for pulmonary arterial hypertension. $N$ Engl $J$ Med 2005; 353: 2148-2157.

29 Galiè N, Brundage BH, Ghofrani HA, et al. Tadalafil therapy for pulmonary arterial hypertension. Circulation 2009; 119: 2894-2903.

30 Kothapalli D, Stewart SA, Smyth EM, et al. Prostacylin receptor activation inhibits proliferation of aortic smooth muscle cells by regulating cAMP response element-binding protein- and pocket protein-dependent cyclin A gene expression. Mol Pharmacol 2003; 64: 249-258.

31 Li RC, Cindrova-Davies T, Skepper JN, et al. Prostacyclin induces apoptosis of vascular smooth muscle cells by a cAMP-mediated inhibition of extracellular signal-regulated kinase activity and can counteract the mitogenic activity of endothelin-1 or basic fibroblast growth factor. Circ Res 2004; 94: 759-767.

32 Billington CK, Ojo OO, Penn RB, et al. cAMP regulation of airway smooth muscle function. Pulm Pharmacol Ther 2013; 26: 112-120.

33 Tuder RM, Cool CD, Geraci MW, et al. Prostacyclin synthase expression is decreased in lungs from patients with severe pulmonary hypertension. Am J Respir Crit Care Med 1999; 159: 1925-1932.

34 Galiè N, Corris PA, Frost A, et al. Updated treatment algorithm of pulmonary arterial hypertension. J Am Coll Cardiol 2013; 62: Suppl. 25, D60-D72.

35 Nagaya N, Sasaki N, Ando M, et al. Prostacyclin therapy before pulmonary thromboendarterectomy in patients with chronic thromboembolic pulmonary hypertension. Chest 2003; 123: 338-343.

36 Pepke-Zaba J, Delcroix M, Lang I, et al. Chronic thromboembolic pulmonary hypertension (CTEPH): results from an international prospective registry. Circulation 2011; 124: 1973-1981.

37 Montani D, Günther S, Dorfmüller P, et al. Pulmonary arterial hypertension. Orphanet J Rare Dis 2013 ; 8: 97.

38 Schweikert B, Pittrow D, Vizza CD, et al. Demographics, clinical characteristics, health resource utilization and cost of chronic thromboembolic pulmonary hypertension patients: retrospective results from six European countries. BMC Health Serv Res 2014; 14: 246.

39 Jensen KW, Kerr KM, Fedullo PF, et al. Pulmonary hypertensive medical therapy in chronic thromboembolic pulmonary hypertension before pulmonary thromboendarterectomy. Circulation 2009; 120: 1248-1254.

40 Condliffe R, Kiely DG, Gibbs JS, et al. Improved outcomes in medically and surgically treated chronic thromboembolic pulmonary hypertension. Am J Respir Crit Care Med 2008; 177: 1122-1127.

41 Jaïs X, D'Armini AM, Jansa P, et al. Bosentan for treatment of inoperable chronic thromboembolic pulmonary hypertension: BENEFiT (Bosentan Effects in iNopErable Forms of chronIc Thromboembolic pulmonary hypertension), a randomized, placebo-controlled trial. J Am Coll Cardiol 2008; 52: 2127-2134.

42 Ghofrani HA, Hoeper MM, Halank M, et al. Riociguat for chronic thromboembolic pulmonary hypertension and pulmonary arterial hypertension: a phase II study. Eur Respir J 2010; 36: 792-799.

43 Mayer E, D'Armini AM, Ghofrani HA, et al. Efficacy of riociguat in patients with inoperable CTEPH vs persistent/recurrent PH after pulmonary endarterectomy (PEA): results from the phase III CHEST-1 study. Eur Respir J 2013; 42: Suppl. 57, 1781.

44 Simonneau G, D'Armini AM, Ghofrani HA, et al. Riociguat for the treatment of chronic thromboembolic pulmonary hypertension: a long-term extension study (CHEST-2). Eur Respir J 2015; 45: 1293-1302.

45 Simonneau G, D’Armini AM, Ghofrani HA, et al. Riociguat for the treatment of chronic thromboembolic pulmonary hypertension (CTEPH): 2-year results from the CHEST-2 long-term extension. Eur Respir J 2014; 44: Suppl. 58, P1802.

46 Bayer HealthCare Pharmaceuticals Inc. Adempas (riociguat) US prescribing information. 2014. http://labeling bayerhealthcare.com/html/products/pi/Adempas_PI.pdf

47 Bayer Pharma AG. Adempas (riociguat) EU Summary of Product Characteristics. 2014. www.ema.europa.eu/docs/ en_GB/document_library/EPAR - Product_Information/human/002737/WC500165034.pdf

48 Hoeper MM, Kramm T, Wilkens H, et al. Bosentan therapy for inoperable chronic thromboembolic pulmonary hypertension. Chest 2005; 128: 2363-2367.

49 Bonderman D, Nowotny R, Skoro-Sajer N, et al. Bosentan therapy for inoperable chronic thromboembolic pulmonary hypertension. Chest 2005; 128: 2599-2603.

50 Hughes RJ, Jais X, Bonderman D, et al. The efficacy of bosentan in inoperable chronic thromboembolic pulmonary hypertension: a 1-year follow-up study. Eur Respir J 2006; 28: 138-143.

51 Seyfarth HJ, Hammerschmidt S, Pankau H, et al. Long-term bosentan in chronic thromboembolic pulmonary hypertension. Respiration 2007; 74: 287-292.

52 Post MC, Plokker HW, Kelder JC, et al. Long-term efficacy of bosentan in inoperable chronic thromboembolic pulmonary hypertension. Neth Heart J 2009; 17: 329-333.

53 Nishikawa-Takahashi M, Ueno S, Kario K. Long-term advanced therapy with bosentan improves symptoms and prevents deterioration of inoperable chronic thromboembolic pulmonary hypertension. Life Sci 2014; 118: 410-413. 
54 Scelsi L, Ghio S, Campana C, et al. Epoprostenol in chronic thromboembolic pulmonary hypertension with distal lesions. Ital Heart J 2004; 5: 618-623.

55 Cabrol S, Souza R, Jais X, et al. Intravenous epoprostenol in inoperable chronic thromboembolic pulmonary hypertension. J Heart Lung Transplant 2007; 26: 357-362.

56 Olschewski H, Simonneau G, Galiè N, et al. Inhaled iloprost for severe pulmonary hypertension. N Engl J Med 2002; 347: 322-329.

57 Ono F, Nagaya N, Okumura $\mathrm{H}$, et al. Effect of orally active prostacyclin analogue on survival in patients with chronic thromboembolic pulmonary hypertension without major vessel obstruction. Chest 2003; 123: 1583-1588.

58 Lang I, Gomez-Sanchez M, Kneussl M, et al. Efficacy of long-term subcutaneous treprostinil sodium therapy in pulmonary hypertension. Chest 2006; 129: 1636-1643.

59 Skoro-Sajer N, Bonderman D, Wiesbauer F, et al. Treprostinil for severe inoperable chronic thromboembolic pulmonary hypertension. J Thromb Haemost 2007; 5: 483-489.

60 Ghofrani HA, Schermuly RT, Rose F, et al. Sildenafil for long-term treatment of nonoperable chronic thromboembolic pulmonary hypertension. Am J Respir Crit Care Med 2003; 167: 1139-1141.

61 Reichenberger F, Voswinckel R, Enke B, et al. Long-term treatment with sildenafil in chronic thromboembolic pulmonary hypertension. Eur Respir J 2007; 30: 922-927.

62 Suntharalingam J, Treacy CM, Doughty NJ, et al. Long-term use of sildenafil in inoperable chronic thromboembolic pulmonary hypertension. Chest 2008; 134: 229-236.

63 Nishimura R, Tanabe N, Sugiura T, et al. Improved survival in medically treated chronic thromboembolic pulmonary hypertension. Circ J 2013; 77: 2110-2117.

64 European Medicines Agency (EMA). European Public Assessment Report (EPAR): Iloprost (Ventavis). Scientific discussion. 2005. www.ema.europa.eu/docs/en_GB/document_library/EPAR_-_Scientific_Discussion/human/000474/ WC500048688.pdf 